\title{
Genetic parameters, genetic trends and inbreeding depression of growth and carcass traits in Pannon terminal line rabbits
}

István Nagy, Petra Gyovai, István Radnai, Henrietta Nagyné Kiszlinger, János Farkas and Zsolt Szendrő

University of Kaposvár, Kaposvár, Hungary

\section{Abstract}

Genetic parameters, inbreeding depression and genetic trends were estimated for average daily gain between the ages of 5-10 weeks and thigh muscle volume (measured in vivo with computerized tomography) in a group of 22098 Pannon terminal line rabbits born between 2006 and 2011 and reared in 3396 litters. The data sets were analysed with bi-variate animal models taking pedigree completeness (complete generation equivalent) into account. By 2011, all rabbits were inbred and the average inbreeding coefficient and complete generation equivalent of the population were $7.69 \%$ and $11.89 \%$, respectively. Estimated heritability was moderate both for average daily gain $(0.23 \pm 0.02)$ and thigh muscle volume $(0.25 \pm 0.03)$. Litter effects were low for both traits $(0.16 \pm 0.00$ and $0.09 \pm 0.01$ respectively). The genetic correlation coefficient estimate between average daily gain and thigh muscle volume was also low $(0.02 \pm 0.08)$. Significant inbreeding depression (per $10 \%$ inbreeding) was only detected for average daily gain $(0.57 \mathrm{~g} / \mathrm{d})$. The estimated annual selection response was substantial both for average daily gain and thigh muscle volume $\left(1.49 \mathrm{~g} / \mathrm{d}\right.$ and $5.84 \mathrm{~cm}^{3}$, respectively), proving the efficiency of the breeding programme.

Keywords: rabbit, average daily gain, thigh muscle volume, inbreeding depression, genetic trend

Abbreviations: ADG: average daily gain, CGE: complete generation equivalent, F: inbreeding coefficient, SD: standard deviation, TMV: thigh muscle volume

Archiv Tierzucht 56 (2013) 18, 191-199

Received: 19 March 2012

doi: 10.7482/0003-9438-56-018

Accepted: 4 July 2012

Online: 1 March 2013

Corresponding author:

István Nagy; email: nagy.istvan@ke.hu

Department of Agricultural Product Processing and Qualification, Faculty of Animal Science, 40. Guba S. str. Kaposvár 7400, Hungary

(c) 2013 by the authors; licensee Leibniz Institute for Farm Animal Biology (FBN), Dummerstorf, Germany. This is an Open Access article distributed under the terms and conditions of the Creative Commons Attribution 3.0 License (http://creativecommons.org/licenses/by/3.0/). 


\section{Introduction}

An efficient breeding programme of any population requires the constant monitoring of its performance for selection criteria traits. The breeding objectives in domesticated animals generally target the improvement of reproduction performance in maternal lines, growth and/or slaughter value in paternal lines. Using conventional methods, the performance of breeding candidates for slaughter traits can only be evaluated by sib or progeny test. Due to its unfavourable properties (high cost, long generation interval), progeny test in rabbit breeding was only practised by Varewyck et al. (1986). Using computer tomography scanning, the body composition of animals can be predicted in vivo. Ten years after the first application of the computer tomography methodology in domesticated species (Skjervold et al. 1981), the Institute of Diagnostic Imaging and Radiation Oncology of the Kaposvár University, Hungary was installed in 1990 which made computer tomography-aided selection possible. In rabbit breeding computer tomography-aided selection is exclusively applied at Kaposvár and so far altogether about 10000 Pannon White and Pannon terminal line rabbits were scanned in vivo. At present, thigh muscle volume (TMV) (summing the surface of 11-12 computer tomography scans) of breeding candidates is determined by computer tomography and the muscle volume obtained is further evaluated with the BLUP methodology to select breeding animals. Contrary to its favourable mathematical properties in case of a closed population structure, the application of the BLUP selection may cause substantially higher inbreeding rate compared to phenotypic selection. The inbreeding level of the population is also affected by the mating scheme (Krieter 1995). Inbreeding effects were observed in several domesticated species (Freyer et al. 2005, Kallweit \& Baulain 2001, Wokac 2003). One of the unfavourable consequences of inbreeding is the reduction of the population mean for traits exhibiting directional dominance (inbreeding depression). The Pannon terminal line rabbit population at Kaposvár is selected for average daily gain (ADG) and for TMV for several generations but so far the efficiency of selection and effects of inbreeding have not been analysed. Therefore, the objective of the present study is to estimate the genetic parameters, genetic trends and inbreeding depression of the Pannon terminal line rabbits for ADG and TMV.

\section{Material and methods}

\section{Foundation population and mating scheme}

Formation of the sire line started with the repeated (2004, 2005 and 2006) sperm import of a genotype showing high ADG. The sperm of five Hungarian and foreign breeds (larger sized) was used to inseminate those Pannon White which had high weight gain. The progeny resulting from these inseminations was used to form the foundation of the sire line. Since 2006, the genotype was selected as a closed population for average daily gain and thigh muscle volume (applying computerized tomography).

Matings of close relatives were avoided using a mating system, where at the beginning of the Pannon terminal line, rabbits were randomly divided into four groups (subpopulations). The purpose of dividing the genotype into groups is to control its inbreeding rate. The matings among the groups are carried out in the following way: 1 우 $\times 4 \sigma^{\top}, 2$ 우 $\times 1 \sigma^{\top}, 3$ 우 $\times 2 \sigma^{\top}$ and 4 우 $\times 3 \sigma^{\top}$. The progeny born as a result of the matings as described above received the 
group number of the sire. Thus descendants of any buck will be placed back to its own group only after four generations.

\section{Population management and traits recorded}

The present analysis was based on data from 22098 Pannon terminal rabbits born between 2006 to 2011 at the Experimental Rabbit Farm of Kaposvár University, Hungary. The evaluated animals were reared in 3396 litters and the total number of the pedigree file was 27869 . The number of the base animals was 151. Descriptive statistics are presented in Table 1. The gender of the rabbits was recorded at weaning. After weaning at 35 days of age, the growing rabbits were kept in fattening cages in a closed rabbit house (2-3 rabbits per cage). The available floor space per rabbit was $0.0650 \mathrm{~m}^{2}$. In winter, the rabbit house was heated to $12-18^{\circ} \mathrm{C}$, during summer the temperature occasionally reached levels as high as $28^{\circ} \mathrm{C}$. Growing rabbits were fed a commercial pellet ad libitum (5-9 weeks: digestible energy $=10.3 \mathrm{MJ} / \mathrm{kg}$, crude protein $=16.1 \%$, crude fat $=2.8 \%$, crude fibre $=16.9 \%$, Robenidin $=66 \mathrm{mg} / \mathrm{kg}$, oxytetracycline $=500 \mathrm{mg} / \mathrm{kg}$, Tiamulin- $\mathrm{f}=50 \mathrm{mg} / \mathrm{kg}$; $9-11$ weeks: digestible energy $=11.0 \mathrm{MJ} / \mathrm{kg}$, crude protein $=16.1 \%$, crude fat $=4.4 \%$, crude fibre $=16.0 \%$ ) and water was available ad libitum from nipple drinker.

Table 1

Descriptive statistics for the analysed traits

\begin{tabular}{|c|c|c|c|c|}
\hline Trait & Year of birth & Mean & SD & Minimum-Maximum \\
\hline ADG,$g / d(n=22098)$ & & 48.58 & 7.41 & $20.29-81.14$ \\
\hline TMV, $\mathrm{cm}^{3}(\mathrm{n}=3724)$ & & 373.4 & 42.15 & 233.4-569.5 \\
\hline $\mathrm{F}, \% / \mathrm{CGE}$ & 2006 & $4.68 / 7.01$ & $3.91 / 0.89$ & $0-27.78 / 3.08-10.08$ \\
\hline $\mathrm{F}, \% / \mathrm{CGE}$ & 2007 & $5.25 / 7.57$ & $3.69 / 1.12$ & $0-29.82 / 2.66-11.42$ \\
\hline $\mathrm{F}, \% / \mathrm{CGE}$ & 2008 & $5.94 / 8.73$ & $2.94 / 0.73$ & $0.86-31.22 / 5.91-10.53$ \\
\hline $\mathrm{F}, \% / \mathrm{CGE}$ & 2009 & $6.88 / 9.81$ & $2.97 / 0.56$ & 2.49-33.05/7.58-11.36 \\
\hline $\mathrm{F}, \% / \mathrm{CGE}$ & 2010 & $6.79 / 10.47$ & $3.42 / 1.36$ & $0-33.05 / 5.19-12.30$ \\
\hline $\mathrm{F}, \% / \mathrm{CGE}$ & 2011 & 7.69/11.89 & $2.61 / 0.67$ & $3.62-29.63 / 9.97-13.70$ \\
\hline
\end{tabular}

The selection of growing rabbits was performed in a two-stage procedure. The first selection criterion was the individual ADG between 5 and 10 weeks of age, while the second was the TMV obtained from computer tomography scanning.

The animals were weighed at 5 and 10 weeks of age to calculate ADG. Rabbits showing the best weight gain (30-40\%) in their kindling batch were subjected to computer tomography examination at 10.5 weeks of age.

According to our methodology, three rabbits were fixed simultaneously in stretch position, lying flat in a specially designed "container during examination without anaesthesia and after eight hours of feed deprivation.

Computer tomography scanning was performed by means of a Siemens Somatom Plus 40 and Siemens Somatom Emotion 6 spiral scanner (both Siemens AG, Erlangen, Germany) of the Institute of Diagnostic Imaging and Radiation Oncology, Kaposvár University. The computer tomography scans (pictures) were adjusted to take $10 \mathrm{~mm}$ thick imaginary slices from the thigh muscle with total overlapping (slice: $10 \mathrm{~mm}$, feed: $10 \mathrm{~mm}$ ) providing direct volumetric information. 


\section{Pedigree analysis}

Inbreeding coefficient (F, given in \%) is defined as the probability that the two alleles at any locus in an individual are identical by descent. Complete generation equivalent (CGE), was calculated according to the following formula:

$$
\frac{1}{N} \sum_{j=1}^{N} \sum_{i=1}^{n_{j}} \frac{1}{2^{g_{i j}}}
$$

where $N$ is the number of animals in the reference population, $N_{j}$ is the total number of ancestors of animal $j$ and $g_{i j}$ is the number of generations between $j$ and its ancestor $i$. Both parameters (F, CGE) were calculated with ENDOG 4.8 software (Gutiérrez et al. 2010) to total available pedigree information.

\section{Statistical models}

Average daily gain and computer tomography-based TMV were evaluated with the REML and BLUP procedures in order to estimate genetic parameters, genetic trends and inbreeding depression.

The computer programs applied in this study were PEST (Groeneveld 1990) and VCE 6 (Groeneveld et al. 2008). The linear model applied was as follows:

$$
y=X b+Z a+W c+e
$$

In case of ADG and TMV the model was:

$$
y=X b+Z a+W c+e
$$

where $y$ is the vector of observations, $\boldsymbol{b}$ is the vector of fixed effects, $\boldsymbol{a}$ is the vector of random animal effects, $\boldsymbol{c}$ is the random vector of common litter effects, $\boldsymbol{e}$ is the vector of random residual effects and finally $X, Z$ and $W$ are incidence matrices relating records to fixed, animal and random litter effects, respectively.

Expected values of $\boldsymbol{a}, \boldsymbol{c}$ and $\boldsymbol{e}$ were $\mathrm{E}(\boldsymbol{a})=\mathrm{E}(\boldsymbol{c})=\mathrm{E}(\boldsymbol{e})=0$. The variance-covariance structure was assumed to be $\mathrm{V}(\boldsymbol{a})=A \sigma_{a^{\prime}}^{2} \mathrm{~V}(\boldsymbol{c})=l \sigma_{c^{\prime}}^{2} \mathrm{~V}(\boldsymbol{e})=l \sigma_{e^{\prime}}^{2}$ and $\operatorname{cov}(\boldsymbol{a}, \boldsymbol{e})=\operatorname{cov}(\boldsymbol{e}, \boldsymbol{a})=0$, where $\boldsymbol{A}$ is the numerator relationship matrix. Also $\operatorname{cov}(y, a)=Z A l \sigma_{a}^{2}$.

The various factor types included in the model are shown in Table 2. The BLUE (Best Linear Unbiased Estimation) estimate for the inbreeding coefficient was used to describe inbreeding depression (per $10 \%$ increase of the coefficient). The significance of inbreeding depression was evaluated using the hypothesis section of PEST. Average breeding values of animals born in the same year were calculated for ADG and TMV (measured between 2006 and 2011). These values were then linearly regressed on the consecutive years using SAS 9.1 software package (SAS Institute Inc., Cary, NC, USA) to calculate genetic trends. Genetic trend estimation was restricted to animals having records for the evaluated traits. 
Table 2

The factors considered for the examined traits

\begin{tabular}{lrccc}
\hline Factor & Level & Type of factor & \multicolumn{2}{c}{ Traits } \\
& & & ADG, g/d & TMV, cm ${ }^{3}$ \\
\hline Computer tomography scan year-month & 55 & fixed effects & - & $\mathrm{x}$ \\
Animal & 27869 & additive genetic effects & $\mathrm{x}$ & $\mathrm{x}$ \\
Litter & 3396 & random effect & $\mathrm{x}$ & $\mathrm{x}$ \\
Year-month & 45 & fixed effects & $\mathrm{x}$ & - \\
Sex & 2 & fixed effects & $\mathrm{x}$ & $\mathrm{x}$ \\
Body weight at computer tomography-scan & 1 & covariant & - & $\mathrm{x}$ \\
Pixel & 3 & fixed effects & - & $\mathrm{x}$ \\
Inbreeding coefficient & 1 & covariant & $\mathrm{x}$ & $\mathrm{x}$ \\
Complete generation equivalent & 1 & covariant & $\mathrm{x}$ & $\mathrm{x}$ \\
\end{tabular}

\section{Results and discussion}

\section{Descriptive statistics}

Inbreeding coefficient for all animals in the pedigree ranged between $0 \%$ and $33.05 \%$, respectively. By 2011, all rabbits were inbred. Average $\mathrm{F}$ continuously increased with the consecutive years (Table 1) but the inbreeding level of the population is still relatively low compared to other rabbit populations (e.g. Kerdiles \& Rochambeau 2002). Gulisija et al. (2006) noted that the inbreeding coefficient has a limited interpretation as an absolute measure of autozygosity, since its value depends on the depth of a pedigree. Te Braake et al. (1994) suggested estimating inbreeding coefficient only for animals with more than 7 ancestral generations and comparing animals with an equal number of ancestral generations in their pedigrees. Similarly to the above suggestion Lutaaya et al. (1999) found that missing pedigree information can cause a severely underestimated inbreeding trend. In the Pannon terminal line the average CGE continuously increased with the successive years and in 2011 reached the value of 7 (Table 1). Consequently the risk of underestimating the inbreeding coefficients was low. The CGE reported by this study exceeded that of several other studies (Baumung \& Sölkner 2002, Goyache et al. 2003, Koenig \& Simianer 2006) analysing the pedigrees of other species with longer generation intervals (for exceptions see Zechner et al. 2002).

\section{Genetic parameters}

Heritability estimates both for ADG and TMV were moderate. The present heritability estimate for ADG was very similar to the value (0.24) previously reported by Nagy et al. (2006). However, it was slightly lower than the estimate of 0.27 reported by Gyovai et al. (2008) in the Pannon White breed. Moura et al. (1997), Gómez et al. (1998) and Larzul et al. (2005) reported higher values of $0.48,0.29$ and 0.34 , respectively, in different kinds of rabbit population. The differences in heritability estimates for ADG can probably be explained on the basis that ADG was measured at different age intervals in the various studies and also by the phenomenon that in the different rabbit populations the genes influencing this trait might have different gene frequencies. 
The estimated heritability for TMV reached higher values (0.26) than the estimate of 0.21 previously observed in Pannon White rabbits by Gyovai et al. on several occasions $(2008,2010$ and 2012). Hermesch et al. (2000) estimated similar values (0.22) in the total weight of the left back leg in Large White and Landrace breeds.

Random litter effect is an environmental effect primarily manifested through the milk production of the doe. Generally, the importance of the random litter effect decreases with the increase in age of the growing rabbits. The magnitude of this effect was low for both traits (Table 4). There were reported similar random litter effects in Pannon White rabbits for ADG (0.18) and for TMV (0.14) by Gyovai et al. (2012). Similarly to these results Moura et al. (1997) also found low magnitude of random litter effects (0.11) for ADG. Somewhat higher (0.20) random litter effects were estimated for ADG by Larzul et al. (2005).

The genetic correlation between ADG and TMV was very low (0.02). Similar correlation value (0.05) was reported between these traits by Gyovai et al. (2012) in the Pannon White breed. The estimated genetic correlation coefficient for the Pannon terminal line is favourable because in the course of the two-stage selection applied, TMV is not affected during the first stage when the rabbits are pre-selected according to their ADG performance.

Table 3

Estimate of heritability (diagonals) and genetic correlation (off-diagonals) ${ }^{1}$

\begin{tabular}{lcc}
\hline Trait & Average daily gain, $\mathrm{g} / \mathrm{d}$ & Thigh muscle volume, $\mathrm{cm}^{3}$ \\
\hline Average daily gain, $\mathrm{g} / \mathrm{d}$ & $0.23(0.02)$ & $0.02(0.08)$ \\
Thigh muscle volume, $\mathrm{cm}^{3}$ & & $0.25(0.03)$ \\
\hline
\end{tabular}

15tandard errors of estimates are given in brackets.

Table 4

Estimate of random litter effects (diagonals) and correlation (off-diagonals)

\begin{tabular}{lcc}
\hline Trait & Average daily gain, $\mathrm{g} / \mathrm{d}$ & Thigh muscle volume, $\mathrm{cm}^{3}$ \\
\hline Average daily gain, $\mathrm{g} / \mathrm{d}$ & $0.16(0.00)$ & $-0.24(0.07)$ \\
Thigh muscle volume, $\mathrm{cm}^{3}$ & & $0.09(0.01)$ \\
\hline
\end{tabular}

${ }^{1}$ Standard errors of estimates are given in brackets.

\section{Inbreeding depression and genetic trends}

Estimated total inbreeding depression (per $10 \%$ inbreeding) was $0.57 \mathrm{~g}$ for $\operatorname{ADG}(P=0.02)$. However, inbreeding had no effect on TMV. Chai et al. (1969) and Ferraz et al. (1992) reported substantial inbreeding depression in rabbits for body weight measured at ten weeks of age. Ferraz (1993) also observed that the inbreeding depression (per $10 \%$ increase of the inbreeding coefficient) varied between 5 and $130 \mathrm{~g}$ for individual body weight measured at 5 to 10 weeks of age in Californian and New Zealand White rabbits. It has to be noted that Chai et al. (1969) practiced full-sib matings (fast inbreeding) for 20 generations, thus the average inbreeding coefficient of their rabbit population was above 0.8 . On the other hand, Ferraz et al. $(1992,1993)$ studied a rabbit population where the level of average inbreeding was about the same as in our study. Fast inbreeding is more harmful than slow inbreeding when natural selection has more time to act, thus slow inbreeding should result in lower 
inbreeding depression (Holt et al. 2005). Traits more distantly related to fitness are generally less affected by inbreeding. Holt et al. (2004) reported that inbreeding did not affect body weight of an inbred strain of mice. In purebred Yorkshire swine Culbertson et al. (1998) found that inbreeding had no effect at all for back fat depth. On the contrary, $10 \%$ increase of the inbreeding coefficient decreased the number of days up to $104.5 \mathrm{~kg}$ by 2.1 days. Similarly the growth traits of Hungarian Landrace pigs shoved only a very slight decrease as a result of inbreeding (Vígh et al. 2008). The results of the different studies examining the effect of inbreeding on carcass traits (e.g. carcass lean $\%$, ham $\%$, lean in ham $\%$, yield \% etc.) in pigs were summarized by Johnson (1989). Estimates of these effects suggest that carcass traits are not greatly affected by inbreeding.

Annual selection responses for ADG and TMV are presented in Table 5. Between 1992 and 1997 Garreau et al. (2000) found substantially smaller annual selection response $(0.6 \mathrm{~g} / \mathrm{d})$ for ADG in the Pannon White rabbit population. Other authors (Estany et al. 1992, Moura et al. 1997, Piles \& Blasco 2003) also found lower selection $(0.45-1.23 \mathrm{~g} / \mathrm{d})$ responses for ADG than those reported here. As the Pannon terminal line showed no superior heritability and selection intensity compared to the other rabbit populations analysed (for ADG), the reason for this difference could be that the body weight of the Pannon terminal line was larger than that of the other breeds studied. The annual genetic trend of TMV was also higher than that of the Pannon White breed $\left(4 \mathrm{~cm}^{3}\right)$ reported by Gyovai et al. (2008). Beside the higher body weight, TMV also showed higher heritability in the Pannon terminal line compared to the Pannon White breed which contributed to its superior genetic trend as well. Our results show that the breeding programme applied can efficiently improve ADG and TMV in the Pannon terminal rabbit population.

Table 5

Selection responses (b) for average daily gain and for thigh muscle volume

\begin{tabular}{lcc}
\hline Trait & $\mathrm{b}$ & $P$ \\
\hline Average daily gain & 1.49 & 0.0001 \\
Thigh muscle volume & 5.84 & 0.0001 \\
\hline
\end{tabular}

\section{References}

Baumung R, Sölkner J (2002) Analysis of pedigrees of Tux-Zillertal, Carinthian Blond and Original Pinzgau cattle population in Austria. J Anim Breed Genet 119, 175-181

Chai CK (1969) Effects of Inbreeding in Rabbits: Inbred lines, discrete characters, breeding performance, and mortality. J Hered 60, 64-70

Culbertson MS, Mabry JW, Misztal I, Gengler N, Bertrand JK, Varona L (1998) Estimation of dominance variance in purebred Yorkshire swine. J Anim Sci 76, 448-451

Estany J, Camacho J, Baselga M, Blasco A (1992) Selection response of growth rate in rabbits for meat production. Genet Sel Evol 24, 527-537

Ferraz JBS, Johnson RK, Van Vleck LD (1992) Use of animal models to estimate the effects of inbreeding on growth and carcass traits of rabbits. J Appl Rabbit Res 15, 143-157

Ferraz JBS, Eler JP, Moretti AS, Ghion E, Masotti N (1993) Effects of inbreeding on growth and slaughter traits of rabbits. Braz J Vet Res Anim Sci 30, 55-63

Freyer G, Hernández-Sánchez J, Cassel BC (2005) A note on inbreeding in dairy cattle breeding. Arch Tierz 48, $130-137$ 
Garreau H, Szendrő Zs, Larzul C, De Rochambeau H (2000) Genetic parameters and genetic trends of growth and litter size traits in the White Pannon breed. In: Proc 7th World Rabbit Congr, Valencia, Spain, 403-408

Goyache F, Gutiérrez JP, Fernández I, Gomez E, Alvarez I, Díez J, Royo LJ (2003) Using pedigree information to monitor genetic variability of endangered populations: the Xalda sheep breeds of Asturias as an example. J Anim Breed Genet 120, 95-105

Gómez EA, Rafel O, Ramon J (1998) Genetic relationships between growth and litter size traits at first parity in a specialized dam line in rabbits. In: Proc. 6th World Congr Genet Appl Livest Prod, Armidale, Australia, Vol 25, 552-555

Groeneveld E (1990) PEST Users' Manual. Institute of Animal Husbandry and Animal Behaviour Federal Research Centre, Neustadt, Germany, 1-80

Groeneveld E, Kovac M, Mielenz N (2008) VCE user's guide and reference manual version 6.0. Friedrich Loeffler Institute, Neustadt, Germany, 1-125

Gulisija D, Gianola D, Weigel KA, Toro MA (2006) Between-founder heterogeneity in inbreeding depression for production in Jersey cows. Livest Sci 104, 244-253

Gutiérrez JP, Goyache F, Cervantes I (2010) ENDOG v4.8. A computer program for monitoring genetic variability of populations using pedigree information. User's Guide. Departamento de Producción Animal. Facultad de Veterinaria. Universidad Complutense de Madrid. Área de Genetica y Reproducción Animal SERIDASomió. 1-45

Gyovai P, Nagy I, Gerencsér Z, Metzger S, Radnai I, Szendrő Z (2008) Genetic parameters and trends of the thigh muscle volume in Pannon White rabbits. In: Proc 9th World Rabbit Congress, Verona, Italy, 115-120

Gyovai P, Nagy I, Gerencsér Zs, Matics Zs, Radnai I, Donkó T, Szendrő Zs (2010) Genetic Parameters Of Growth In Vivo Computer Tomography Based And Reproduction Traits In Pannon White Rabbits. In: Proc 9th World Congr Genet Appl Livest Prod, Leipzig, Germany, CD-ROM, Commun. No. 343

Gyovai P, Nagy I, Gerencsér Zs, Matics Zs, Radnai I, Donkó T, Bokor Á, Farkas J, Szendrő Zs (2012) Genetic parameters for litter weight, average daily gain and thigh muscle volume measured by in vivo Computer Tomography technique in Pannon White rabbits. Livest Sci 144, 119-123

Hermesch S, Luxford BG, Graser HU (2000) Genetic parameters for lean meat yield, meat quality, reproduction and feed efficiency traits for Australian pigs: 1. Description of traits and heritability estimates. Livest Prod Sci 65, 239-248

Holt M, Nicholas FW, James JW, Moran C, Martin ICA (2004) Development of a highly fecund inbred strain of mice. Mamm Genome 15, 951-959

Holt M, Meuwissen T, Vangen $\mathrm{O}$ (2005) The effect of fast created inbreeding on litter size and body weights in mice. Genet Sel Evol 37, 523-537

Johnson RK (1989) Inbreeding effects on reproduction, growth and carcass traits. In: Young LD (ed) Genetics of Swine. USDA-ARS, Clay Center, Nebraska, USA, 107-109

Kallweit E, Baulain U (2001) Reproduction performance and degree of inbreeding in small Finnsheep population during a 34-year period. Arch Tierz 44 Special Issue, 263-270

Kerdiles V, de Rochambeau H (2002) A genetic description of two strains of rabbits. J Anim Breed Genet 119, 25-33

Krieter J (1995) Effects of different mating strategies on the selection response, inbreeding and genetic variance in a closed pig population. Arch Tierz 38, 633-642

Koenig S, Simianer H (2006) Approaches to the management of inbreeding and relationship in the German Holstein dairy cattle population. Livest Sci 103, 40-53

Larzul C, Gondret F, Combes S, de Rochambeau H (2005) Divergent selection on 63-day body weight in the rabbit: respose on growth, carcass and muscle traits. Genet Sel Evol 37, 105-122

Lutaaya E, Misztal I, Bertrand JK, Mabry JW (1999) Inbreeding in populations with incomplete pedigrees. J Anim Breed Genet 116, 475-480

Moura AS, Kaps M, Vogt DW, Lamberson WR (1997) Two-way selection for daily gain and feed conversion in a composite rabbit population. J Anim Sci 75, 2344-2349 
Nagy I, Ibánez N, Romvári R, Mekkawy W, Metzger Sz, Horn P, Szendrő Zs (2006) Genetic parameters of growth and in vivo computerized tomography based carcass traits in Pannon White rabbits. Livest Sci 104, 46-52

Piles M, Blasco A (2003) Response to selection for growth rate in rabbits estimated by using a control cryopreserved population. World Rabbit Sci 11, 53-62

Skjervold H, Grønseth K, Vangen O, Eversen A (1981) In vivo estimation of body composition by computerized tomography. J Anim Breed Genet 98, 77-79

Te Braake MFH, Groen AF, van der Lugt AW (1994) Trends in inbreeding in Dutch Black and White dairy cattle. J Anim Breed Genet 111, 356-366

Varewyck H, Bouquet $Y$, Van Zeveren A (1986) A progeny test for carcass quality in meat rabbits. Arch Geflügelk 50, 26-31

Vígh Z, Gyovai P, Csató L, Bokor Á, Farkas J, Radnóczi L, Komlósi I, Nagy I (2008) Effect of inbreeding on lean meat percentage and average daily gain in Hungarian Landrace pigs. Arch Tierz 51, 541-548

Wokac RM (2003) On the importance of inbreeding at Tauernschecken goats. Arch Tierz 46, 455-469 [in German]

Zechner P, Sölkner J, Bodó I, Druml T, Baumung R, Achmann R, Marti E, Habe F, Brem G (2002) Analysis of diversity and population structure in the Lipizzan horse breed based on pedigree information. Livest Prod Sci 77, 137-146 